\title{
RANCANG BANGUN ALAT PENGUPAS KULIT BIJI MELINJO UNTUK PENGEMBANGAN USAHA MIKRO KECIL DAN MENENGAH DI DESA MESOYI KECAMATAN TALUN KABUPATEN PEKALONGAN
}

\author{
Muhammad Khafidh \\ Jurusan Teknik Mesin, Fakultas Teknologi Industri, Universitas Islam Indonesia \\ Jl. Kaliurang km 14,5 Sleman, Yogyakarta \\ Email : khafidh@uii.ac.id
}

\begin{abstract}
ABSTRAK
Melinjo merupakan salah satu jenis tanaman perkebunan yang cukup banyak terdapat di Indonesia, khususnya di pulau Jawa. Melinjo banyak dimanfaatkan bijinya untuk diolah menjadi emping. Desa Mesoyi merupakan salah satu sentra penghasil melinjo di Kabupaten Pekalongan. Hal itu yang membuat di Desa Mesoyi terdapat banyak UMKM yang bergerak dalam bidang pengolahan melinjo menjadi emping. Namun pengolahan melinjo menjadi emping di banyak UMKM masih menggunakan cara tradisional sehingga produktivitasnya masih relatif rendah. Proses pembuatan emping dimulai dari penjemuran melinjo sehingga menjadi melinjo klatak, proses sangrai, pengupasan kulit keras, pemipihan dan terakhir dijemur untuk menjadi emping yang siap dipasarkan. Dalam penelitian ini akan difokuskan pada pembuatan paket teknologi tepat guna untuk proses pengelupasan kulit keras. Hasil yang diperoleh menunjukkan bahwa produktivitas alat pengupas kulit biji melinjo mencapai 39,6 kg per jam atau meningkat 6 kali lipat dibandingkan proses manual yang hanya mencapai 6,36 kg per jam. Dari segi konsumsi listrik, alat ini membutuhkan biaya Rp 831,37 per hari dengan asumsi penggunaan alat selama 6 jam per hari. Efisiensi alat pengupas kulit biji melinjo ini adalah $86,5 \%$.
\end{abstract}

Kata kunci : kulit keras, melinjo, alat pengupas, UMKM

\section{PENDAHULUAN}

Indonesia merupakan daerah yang subur, hampir semua jenis tanaman dapat tumbuh diatasnya. Penduduk Indonesia banyak yang memanfaatkan tanah subur negerinya untuk dijadikan lahan pertanian, perkebunan dan sebagainya. Karena banyaknya perkebunan di Indonesia, beraneka macam tanaman hortikultura pun dapat jumpai. Dari sekian banyak jenis tanaman hortikultura, tanaman melinjo merupakan salah satu tanaman hortikultura berumur panjang yang berpotensi besar dalam peningkatan produksi hortikultura, sebab dari tanaman melinjo dapat diperoleh beberapa jenis hasil seperti daun, buah, kulit buah, serat kulit batang dan batang pohon melinjo. Yang paling banyak dimanfaatkan oleh masyarakat dari tanaman melinjo adalah daun dan buahnya.

Daun melinjo yang masih muda (so) merupakan salah satu bahan sayuran bergizi tinggi dan tersedia secara terus - menerus, kayunya dapat dipakai sebagai bahan papan dan alat rumah tangga sederhana, sedangkan daging buah melinjo yang telah cukup masak atau tua, merupakan bahan utama pembuatan emping melinjo yang lezat. Emping melinjo merupakan salah satu makanan ringan yang bernilai gizi tinggi.

Tanaman melinjo memiliki klasifikasi sebagai berikut (Haryoto, 1998) :
a. Divisi : Spermatophyta
b. Subdivisi : Gymnospermae
c. Kelas : Gnetinae
d. Ordo : Gnetales
e. Famili : Gnetaceae
f. Genus : Gnetum
g. Spesies : Gnetum gnemon $L$

Tanaman melinjo berbatang tegak lurus dengan ketinggian mencapai 25 meter. Ada dua jenis bentuk tanaman melinjo yakni bertajuk kerucut dan piramida. Tanaman melinjo termasuk tanaman bercabang banyak, tetapi ranting dan cabangnya tidak menempel kuat pada batang tanaman sehingga mudah lepas. Batang tanaman dan cabangnya berbentuk bulat dengan warna hitam keabu-abuan. 
Penanaman melinjo dapat dilakukan dengan menggunakan bibit asal biji, cangkok okulasi, sambungan atau stek. Pohon melinjo mulai berbuah setelah berumur 5 - 7 tahun. Sedangkan pohon yang berasal dari bibit bukan biji hanya memerlukan waktu 3 - 4 tahun untuk mulai berbuah (Tim Penulis PS, 1992).

Biji melinjo menjadi bahan baku pembuatan emping, sedangkan kulitnya yang keras dapat dimanfaatkan sebagai bahan bakar dalam proses pengolahannya kulit luarnya yang lunak selain dapat digunakan sebagai bahan sayuran dapat juga digoreng kering sebagai kudapan. Daun muda mellinjo dapat dimanfaatkan sebagai bahan sayuran. Kayu melinjo juga dapat dimanfaatkan untuk perkakas dapur, bahan bangunan dan kayu bakar. Juga kulit batang melinjo dapat digunakan untuk bahan pembuatan tali.
Tanaman melinjo umumnya mengalami tiga kali masa panen per tahun. Pemetikan buah melinjo tergantung pada tujuan penggunaan. Jika akan dijadikan bahan sayur, pemetikan daun muda atau buah muda dapat dilakukan sewaktu - waktu. Tetapi jka akan dijadikan bahan baku emping, maka pemetikan buah melinjo yang terbaik adalah bila buah tersebut telah tua.

Desa Mesoyi merupakan salah satu desa yang terletak di Kecamatan Talun Kabupaten Pekalongan. Kecamatan Talun terletak di bagian timur dari Kabupaten Pekalongan, wilayahnya mencakup 10 desa seluas 58,57 $\mathrm{km}^{2}$ dengan kondisi alam berupa perbukitan dan kondisi tanah yang cukup subur sehingga memungkinkan untuk ditumbuhi berbagai macam tumbuhan buah - buahan (Badan Pusat Statistik Kab.Pekalongan). Produksi buah - buahan di Kecamatan Talun dapat dilihat dari tabel 1 .

Tabel 1. Produksi Pertanian Buah-Buahan di Kecamatan Talun.

(UPTD Pertanian Kecamatan Talun)

\begin{tabular}{|c|c|c|c|c|c|}
\hline \multirow{2}{*}{ Jenis Tanaman } & \multicolumn{2}{|c|}{ Banyaknya Pohon } & \multirow{2}{*}{$\begin{array}{c}\text { Produksi } \\
\text { (Kw) }\end{array}$} \\
\cline { 3 - 4 } & $\begin{array}{c}\text { Tidak } \\
\text { Menghasilkan }\end{array}$ & Menghasilkan & & \\
\hline & & & & & \\
2 & Sirsak & - & 300 & 300 & 1440,0 \\
3 & Mangga & 2.400 & 2.747 & 5.147 & 19,0 \\
4 & Rambutan & 1.450 & 1.418 & 2.868 & 1843,0 \\
5 & Durian & 8.435 & 4.196 & 12.631 & 704,0 \\
6 & Jambu Air & 16 & 62 & 78 & 78,0 \\
7 & Pepaya Biji & 2.125 & 3.984 & 6.109 & 528,0 \\
8 & Pisang & 9.400 & 453 & 472 & 16,0 \\
9 & Nanas & - & 18.886 & 28.286 & 42,0 \\
10 & Salak & 1.500 & 43.362 & 44.862 & 0,0 \\
11 & Nangka & 2.200 & 5.621 & 7.821 & 1686,0 \\
12 & Belimbing & 75 & 635 & 710 & 12,0 \\
13 & Sukun & 43 & 32 & 75 & 0,0 \\
14 & Jengkol & 2.113 & 9.540 & 11.653 & 24920,0 \\
15 & Petai & 845 & 1.756 & 2.601 & 0,0 \\
$\mathbf{1 6}$ & Melinjo & $\mathbf{2 1 0}$ & $\mathbf{8 2 . 9 2 2}$ & $\mathbf{8 3 . 1 3 2}$ & $\mathbf{4 2 6 0 0 , 0}$ \\
\hline
\end{tabular}

Dari tabel produksi buah - buahan di kecamatan Talun tersebut menunjukkan bahwa pohon melinjo mendominasi produksi pertanian buah - buahan di Talun, produksinya pun yang paling banyak, yaitu sebesar 42.600 Kwintal. Desa Mesoyi 
merupakan salah satu sentra melinjo di Talun. Salah satu pemanfaatan melinjo yang paling banyak dilakukan adalah dengan pembuatan emping. Gambar 1 merupakan proses pembuatan emping dari melinjo.

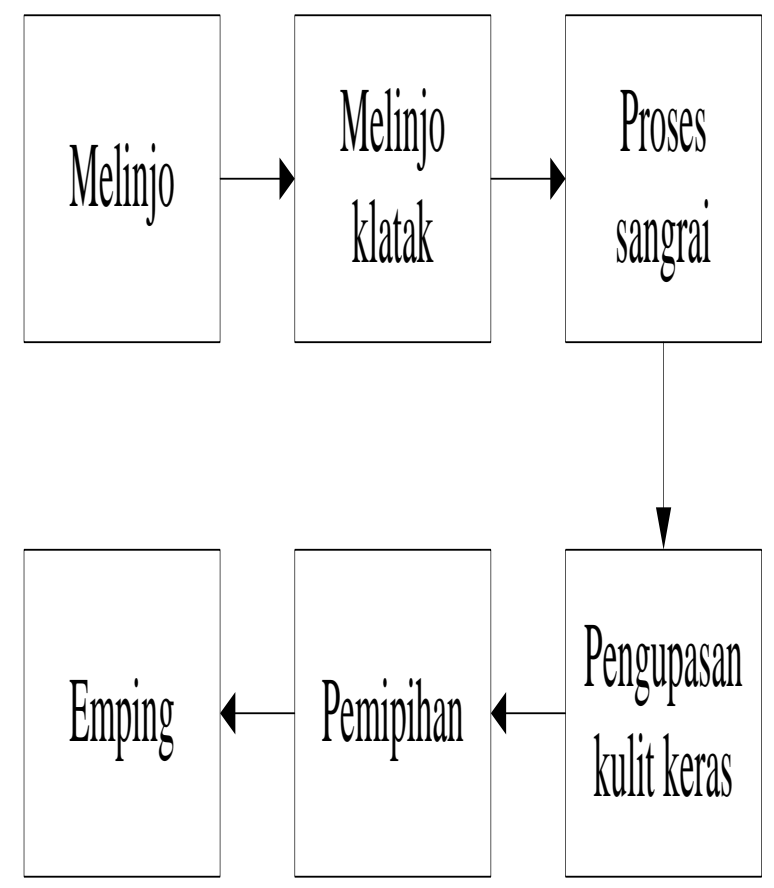

Gambar 1. Proses Pembuatan Emping Dari Melinjo.

Dalam proses pembuatan emping, langkah pertama melinjo yang dipetik dari pohon dijemur sampai kering sehingga menghasilkan melinjo klatak. Dari melinjo klatak akan dilakukan proses sangrai menggunakan media pasir yang dipanaskan. Melinjo yang setelah disangrai akan dikupas kulit kerasnya dengan cara dipukul. Biji melinjo yang sudah dikupas kulit kerasnya selanjutnya akan dipipihkan. Terakhir akan dijemur sampai kering sehingga menghasilkan emping.

Proses pembuatan emping yang dilakukan oleh UMKM masih menggunakan proses manual. Hal ini menimbulkan efektifitas produksi yang rendah. Penelitian ini akan difokuskan pada pembuatan alat tepat guna untuk membantu proses pengupasan kulit keras yang sebelumnya dilakukan dengan cara ditumbuk secara manual.

\section{METODE PELAKSANAAN}

Dalam penelitian ini, secara umum terdiri dari 4 tahap penelitian. Antara lain :

a. Desain

Dalam perancangan alat pengupas kulit biji melinjo mempertimbangkan kaidah dalam perancangan teknik (Shigley Joseph E, 1989). Parameter penting yang dijadikan acuan adalah alat ini dapat mempunyai fungsi : (1) Pengupasan kulit keras melinjo yang efektif dan efisien, (2) Pemisahan antara biji melinjo dengan kulit keras yang sudah dikupas, (3) Pengoperasian yang mudah, (4) Biaya pembuatan yang murah, (5) Biaya pengoperasian yang murah. Gambar 2.1(a) menunjukkan desain 3D dari alat pemecah kulit melinjo yang akan dibuat.

\section{b. Fabrikasi Alat}

Tahap berikutnya adalah fabrikasi alat. Desain alat yang sudah jadi kemudian diproduksi menjadi sebuah alat yang siap untuk dipakai. Gambar 2.1(b) menunjukkan salah satu tahap dalam pembuatan alat pemecah kulit biji melinjo.

\section{c. Pengujian Alat}

Alat pemecah kulit melinjo yang sudah jadi selanjutnya dilakukan pengujian untuk melihat performa dari alat tersebut. Pengujian dilakukan di bengkel pembuatan alat untuk menentukan setting alat yang optimum. Gambar 2.1(c) menunjukkan proses pengujian alat pemecah kulit biji melinjo.

\section{d. Implementasi Alat}

Tahap akhir dari penelitian ini adalah implementasi alat pemecah kulit biji melinjo ke UMKM. Dalam penelitian ini, UMKM yang dipilih adalah salah satu UMKM yang berada di desa Mesoyi, Kecamatan Talun, Kabupaten Pekalongan. Dalam tahp ini, beberapa parameter dalam penggunaan alat ini juga dievaluasi dan dibandingkan dengan proses manual yang selama ini dilakukan oleh UMKM. 


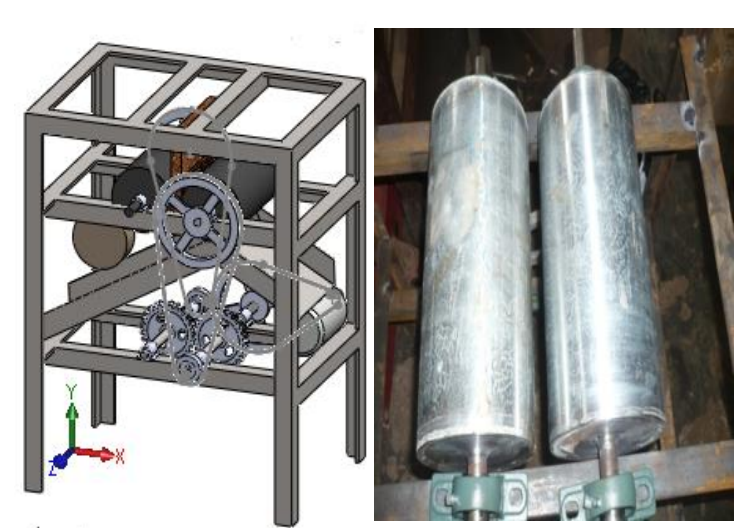

a

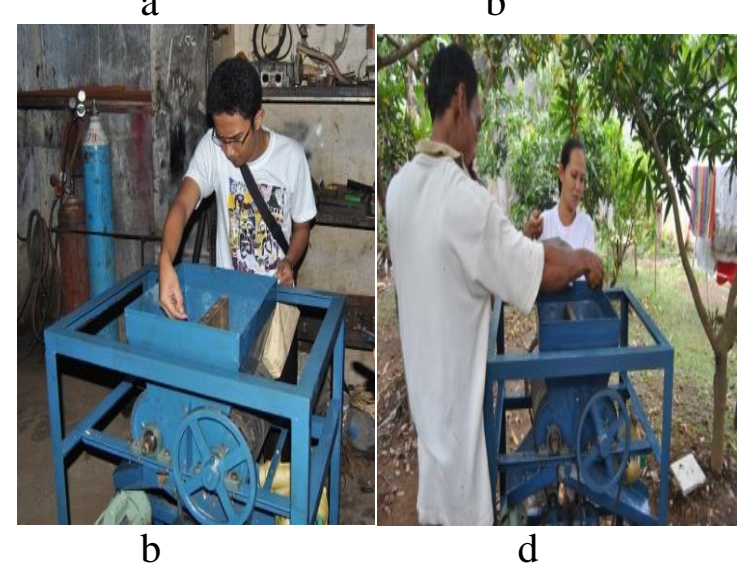

Gambar 2. Tahap Penelitian;

(a) Desain Alat, (b) Fabrikasi Alat,

(c) Pengujian Alat, (d) Implementasi Alat di UMKM.

\section{HASIL DAN PEMBAHASAN}

\subsection{Rancang Bangun Alat}

Alat pengupas kulit biji melinjo yang selesai dibuat ditunjukkan dalam Gambar 3. Dari berbagai kemungkinan alternatif proses pengupasan kulit biji melinjo, dalam perancangan ini menggunakan dua buah rol besi yang dilapisi karet dan diantara kedua rol terdapat papan dari kayu yang bergerigi pada permukaannya.

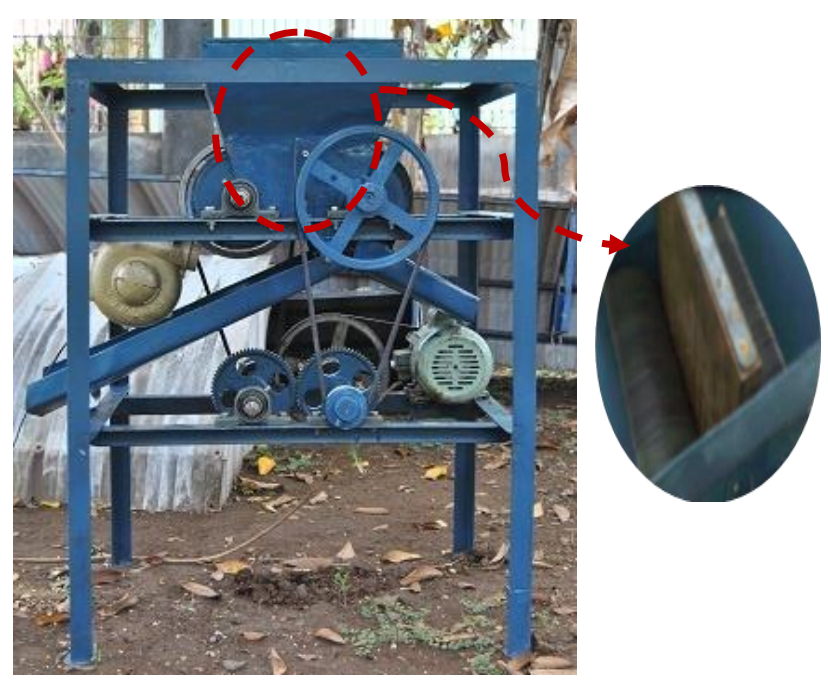

Gambar 3. Alat Pengupas Kulit Biji Melinjo.

Setelah didapat metode pengupasan, maka selanjutnya dilakukan perancangan mekanisme penggerak dari rol pengupas. Pada perancangan ini menggunakan mekanisme sistem transmisi daya berupa pulli dan belt. Daya dari motor menggerakkan puli yang kemudian memutar poros untuk seterusnya memutar rol bagian kanan. Sedangkan untuk memutar rol sebelah kiri memakai poros. Penggerak rol yang digunakan semuanya menggunakan sistem puli. Keluaran yang di dapat dari sistem ini adalah gerakan rol yang bergerak rotasi.

Diantara kedua rol ini terdapat kayu bergerigi yang berfungsi untuk menggerus biji melinjo. Setelah kulit melinjo terlepas dari daging bijinya, digunakan blower untuk memisahkan antara biji melinjo dan kulitnya. Biji melinjo akan jatuh ke sisi kiri dari alat, sedangkan kulitnya akan jatuh ke sisi kanan dari alat. Hal ini dilakukan untuk memudahkan dalam pengambilan daging biji yang bersih untuk dilakukan proses selanjutnya. 
Alat pengupas kulit melinjo ini menggunakan sistem transmisi daya berupa puli dan belt sehingga output gerakan dari rol pengupas bergerak rotasi secara stabil. Untuk mengatur kecepatan putaran digunakan puli yang berbeda diameter antara puli atas dan bawah.

\subsection{Performansi Alat Pengupas Kulit Biji Melinjo}

Alat pengupas kulit biji melinjo diuji performanya dan dibandingkan dengan pengupasan manual. Tabel 2 menunjukkan perbandingan jumlah biji melinjo yang dapat dikupas antara proses manual dan menggunakan alat.

Tabel 2 Perbandingan Produksi Antara

Proses Manual dan Menggunakan Alat.

\begin{tabular}{|c|c|c|c|}
\hline No. & Waktu & $\begin{array}{c}\text { Menggunakan } \\
\text { alat }\end{array}$ & $\begin{array}{l}\text { Proses } \\
\text { manual }\end{array}$ \\
\hline 1. & $\begin{array}{l}1 \text { menit } \\
\text { pertama }\end{array}$ & $0,6 \mathrm{~kg}$ & $0,09 \mathrm{~kg}$ \\
\hline 2. & $\begin{array}{l}1 \text { menit } \\
\text { kedua }\end{array}$ & $0,5 \mathrm{~kg}$ & $0,13 \mathrm{~kg}$ \\
\hline 3. & $\begin{array}{l}1 \text { menit } \\
\text { ketiga }\end{array}$ & $0,7 \mathrm{~kg}$ & $0,1 \mathrm{~kg}$ \\
\hline 4. & $\begin{array}{l}1 \text { menit } \\
\text { keempat }\end{array}$ & $0,7 \mathrm{~kg}$ & $0,11 \mathrm{~kg}$ \\
\hline 5. & $\begin{array}{l}1 \text { menit } \\
\text { kelima }\end{array}$ & $0,8 \mathrm{~kg}$ & $0,1 \mathrm{~kg}$ \\
\hline \multicolumn{2}{|c|}{$\begin{array}{l}\text { Rata-rata per } \\
\text { menit }\end{array}$} & $0,66 \mathrm{~kg}$ & $0,106 \mathrm{~kg}$ \\
\hline
\end{tabular}

Tabel 2 di atas menunjukkan bahwa perbandingan produktivitas pengolahan secara manual dan dengan permesinan mempunyai selisih yang cukup signifikan. Pada pengolahan manual rata - rata menghasilkan biji melinjo kupasan sebanyak $0,106 \mathrm{~kg}$ per menitnya atau $6,36 \mathrm{~kg}$ per jam. Sedangkan pada penggunaan alat pengupas kulit biji melinjo dapat menghasilkan produksi $0,66 \mathrm{~kg}$ per menit atau 39,6 kg per jam.

Efisiensi dari alat pengupas kulit biji melinjo belum mencapai $100 \%$. Dalam penggunaan alat ini, ada beberapa biji melinjo yang tidak terkelupas. Hal ini disebabkan oleh ukuran biji melinjo yang bervariasi dan kekerasan dari kulit biji melinjo yang berbeda antara satu dengan yang lainnya. Dalam pengujian alat ini, didapatkan hasil efisiensi dari alat ini sebesar $86,5 \%$. Gambar 3.2 menunjukkan biji melinjo setelah dikupas dengan alat pengupas kulit biji melinjo, dimana menunjukkan bahwa ada beberapa kulit biji melinjo yang belum terkelupas.

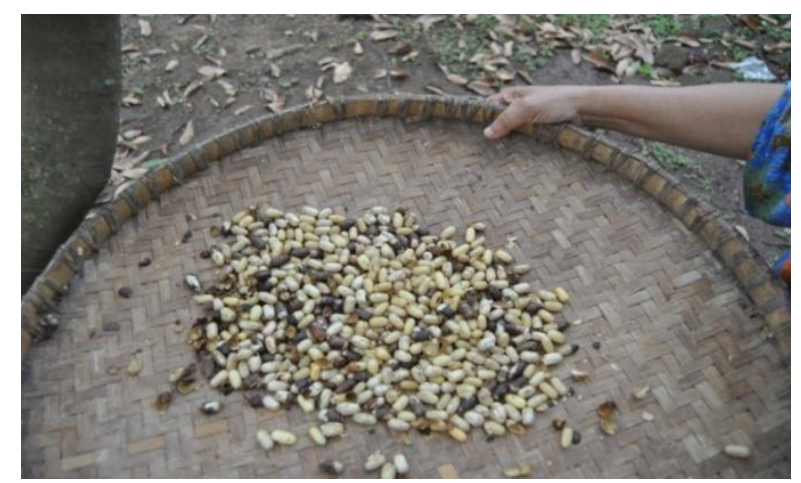

Gambar 3. Biji Melinjo Hasil Pengupasan Dengan Alat.

\subsection{Analisa Perhitungan Biaya Listrik Yang Digunakan}

Analisa biaya listrik sangat diperlukan untuk mengetahui berapa biaya tambahan yang harus dikeluarkan oleh UMKM apabila mengganti proses manual dengan menggunakan alat pengupas kulit biji melinjo.

Berikut ini adalah analisa biaya penggunaan listrik dari alat ini :

- Motor listrik 0,25 Hp = 0,186 Kwh.

- Asumsi 1 hari digunakan 6 jam, dengan harga $1 \mathrm{KWh}=\mathrm{Rp} 605,00$.

- Maka biaya pemakaian motor listrik dalam 1 hari $=0,186 \times \operatorname{Rp} 605,00 \times 6 .=$ Rp 675,18.

- Blower $0.43 \mathrm{~A}, 100 \mathrm{~V}$.

- Daya $\mathrm{P}=\mathrm{V}$ x I.

$=100 \times 0.43$.

$=0.043 \mathrm{KWh}$.

- Asumsi 1 hari digunakan 8 jam, dengan harga $1 \mathrm{KWh} \quad=\operatorname{Rp} 605,00$.

Maka biaya pemakaian blower dalam 1 hari $=0.043 \times \operatorname{Rp} 605,00 \times 6$.

Jadi total biaya listrik dalam sehari $=\mathrm{Rp}$ $675,18+=\operatorname{Rp} 156,09=\operatorname{Rp} 831,27$. 


\subsection{Perbandingan Dengan Alat Sejenis yang Ada Di Pasaran}

Alat pemecah kulit biji melinjo ini relatif murah bila dibandingkan dengan alat sejenis yang ada dipasaran. Biaya produksi alat ini berkisar 4 juta rupiah untuk kapasitas 39,6 $\mathrm{kg} / \mathrm{jam}$ sedangkan alat yang sudah ada dipasaran harganya berkisar 7 juta rupiah dengan kapasitas $20 \mathrm{~kg} / \mathrm{jam}$. Sistem pengupas melinjo yang menggunakan 2 rol dengan ditengah - tengahnya terdapat kayu bergerigi juga menjadi keunggulan alat ini karena bisa menjadi input ganda dalam proses pengupasan kulit melinjo. Hal ini dapat meningkatkan produktivitas hingga dua kali lipat lebih banyak dibanding alatalat yang sejenis.

Secara desain, alat ini sangat ergonomis karena ketinggiannya didesain agar dapat digunakan dengan mudah, tidak terlalu rendah dan tidak terlalu tinggi. Alat ini sudah disesuaikan dengan kenyamanan penggunaan sesuai tinggi rata - rata orang Indonesia. Kemudahan dari alat ini yang lain adalah dalam hal penggunaan hanya cukup mencolokkan kabel listrik dan memasukkan melinjo ke dalam hopper, sehingga dapat digunakan oleh berbagai kalangan termasuk orang yang kurang terlatih.

\section{KESIMPULAN}

Dari penelitian ini dapat diambil beberapa

kesimpulan, yaitu:

1. Produktivitas alat pengupas kulit biji melinjo dibandingkan dengan proses manual mempunyai perbandingan 6:1. Pada penggunaan alat menghasilkan 0,66 $\mathrm{kg} / \mathrm{jam}$ sedangkan proses manual menghasikan $0,106 \mathrm{~kg} / \mathrm{jam}$.

2. Efisiensi dari alat pengupas kulit biji melinjo adalah $86,5 \%$.

3. Biaya listrik dalam penggunaan alat pengupas biji melinjo per hari adalah $\mathrm{Rp}$. 831,27 .

4. Biaya produksi alat berkisar 4 juta rupiah untuk kapasitas 39,6 kg/jam sedangkan alat yang sudah ada dipasaran harganya berkisar 7 juta rupiah dengan kapasitas 20 $\mathrm{kg} / \mathrm{jam}$.

\section{UCAPAN TERIMAKASIH}

Peneliti mengucapkan terima kasih kepada Direktorat Jenderal Pendidikan Tinggi, Departemen Pendidikan dan Kebudayaan, Republik Indonesia untuk pendanaan hibah Program Kreativitas Mahasiswa bidang Teknologi.

\section{DAFTAR PUSTAKA}

Haryoto. Membuat emping melinjo. Yayasan Kanisius. Yogyakarta, 1998.

Tim penulis PS. Budidaya dan pengolahan melinjo. Penebar swadaya. Jakarta, 1992.

Badan Pusat Statistik Kabupaten Pekalongan.

UPTD Pertanian Kecamatan Talun.

Shigley Joseph E. Mechanical Engineering Design 5th Edition. McGraw-Hill Book Co. USA, 1989. 